\title{
5. Riverine Disposal of Mining Wastes in Porgera: Capitalist Resource Development and Metabolic Rifts in Papua New Guinea
}

\section{JERRY K. JACKA}

\section{Introduction}

It is mid-morning and Epe and I are walking along the four-wheel drive road in Tipinini that connects the hamlets of Kolatika, Lese and Yomondaka with the main road (Figure 5.1). We are on our way to his garden in Yomondaka to join his wife, two daughters and son who are at work, weeding and harvesting. As we cross the bridge over the Wateya River, we see Jonah Wuambo just upstream, sitting fully clothed underneath a small waterfall in a pool of water. The water pours directly onto Jonah's head, encasing him in a curtain of frigid water. 'Jonah must be sick', Epe says. Despite Porgera's location at only $5^{\circ}$ south of the Equator, the high altitude means that the rivers are cool, and sitting in a cold waterfall while sick seems counter-intuitive to me-a point that I make to Epe. 'No,' he replies, 'the water will wash his sickness away. It will make him feel better later.' Epe and I stand at the railing of the bridge watching Jonah for a few minutes; he eventually notices us and waves weakly. We wave back and continue on to Epe's family's garden. 


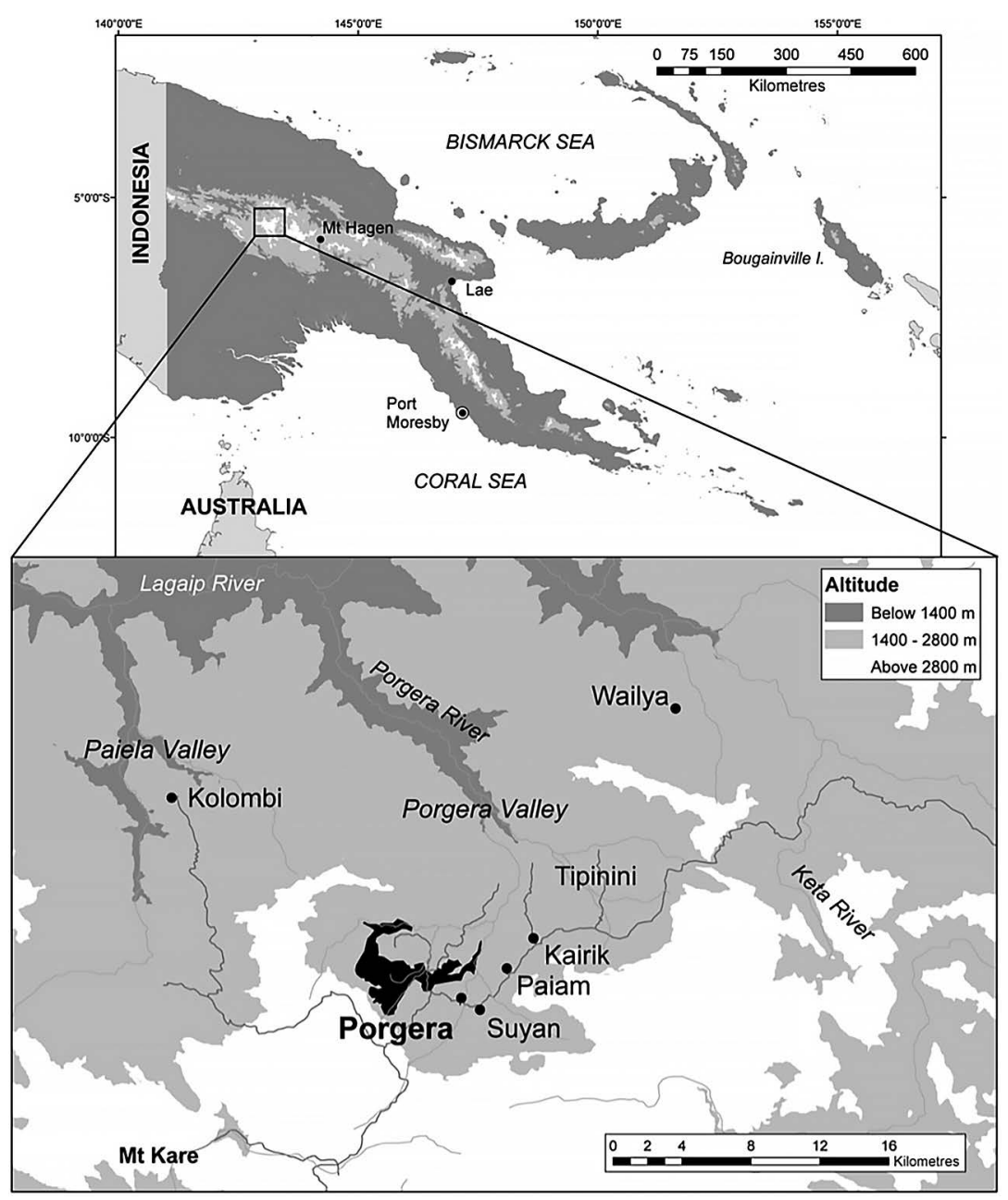

Figure 5.1 The Porgera Valley.

Source: Cartography by the author.

Water in its many forms — as rain, rivers or ponds—is an elemental force in Porgeran culture and ecology. Water, or ipa in both of the local languages (Ipili and Enga), figures centrally in curing rituals and in ideas about the maintenance of fertility in people, flora and fauna, and even the land. There is also an opposition between moving water and still water, ${ }^{1}$ with water in motion considered to be more efficacious in its power to heal and nurture (see Weiner 1991: 99-105). This concept of motion highlights

1 See Hviding, this volume, on the opposition between salt and fresh water in a coastal community. 
another key metaphor in Porgeran philosophy that contrasts movement with stasis. In most cases, stasis is a result of some form of blockage. Most illnesses are perceived as being due to the inability of fluids to move through the body. Cures for sickness either utilise or emulate the free flow of liquids, and sitting under waterfalls, drinking large quantities of water and invoking the names of certain sappy trees in healing spells are just some of the ways that fluidity is deployed.

The cultural significance of clean, flowing water for promoting health in people and the land is in direct contrast to the activities of the Porgera gold mine. Built in 1990, the Porgera mine is one of only four mines in the world that practice the riverine disposal of mining wastes (Vogt 2012). Every day, 17,000 metric tonnes of mining tailings and waste rock are dumped into two major tributaries of the Porgera River. The past 28 years of mining activities have resulted in two massive rock glaciers, each tens of millions of metric tonnes in size, moving slowly down the river valley, erasing gardens, homesteads and past sites of artisanal alluvial mining. The Porgera River often runs blood-red from the iron oxides released during the ore crushing phase of mining. Other toxic metals are potentially altering downstream ecologies and livelihoods in manifold ways (CSIRO 1996; Shearman 2001), and the ensuing perception of pollution in Porgera has profound social and cultural effects (see Beck 1992). Riverine pollution is the legacy of mining development in Papua New Guinea (PNG) (see also Banks et al. 2013). Earlier projects, such as the Panguna mine in North Solomons Province and the Ok Tedi mine in Western Province, have proven to be socially, economically and ecologically costly as downstream communities have either halted the mining project, as in the case of Panguna (May and Spriggs 1990), or been granted a multi-million dollar out-of-court settlement, as happened at Ok Tedi (Kirsch 2006, 2014).

My concern in this chapter is to examine the implications of turning a critical force in Porgeran well-being-namely rivers-into dumping grounds for resource extraction (see Figure 5.2). In a cultural context in which humans and their natural environment share life-giving powers, how does riverine pollution alter social and ecological relationships? Building upon Marx's concept of metabolism, John Foster argues that capitalism creates 'metabolic rifts' between the social and natural worlds (Foster 2000: 155-70). Or as Marx himself put it: 
It is not the unity of living and active humanity with the natural, inorganic conditions of their metabolic exchange with nature, and hence their appropriation of nature, which requires explanation or is the result of a historic process, but rather the separation between these inorganic conditions of human existence and this active existence (Marx 1973: 489, emphasis in original).

For Marx, the natural world was 'the inorganic body' of humanity (Foster 2000: 72), and he conceived of the metabolic rift in terms of the way that capitalist agriculture consumed the fertility of the soil. I argue that these same processes are at play in Porgera but in a fluvial form, so my goal in this chapter is to explore the social and ecological implications of the metabolic rift that mining has created between Porgerans and their aquatic environments.

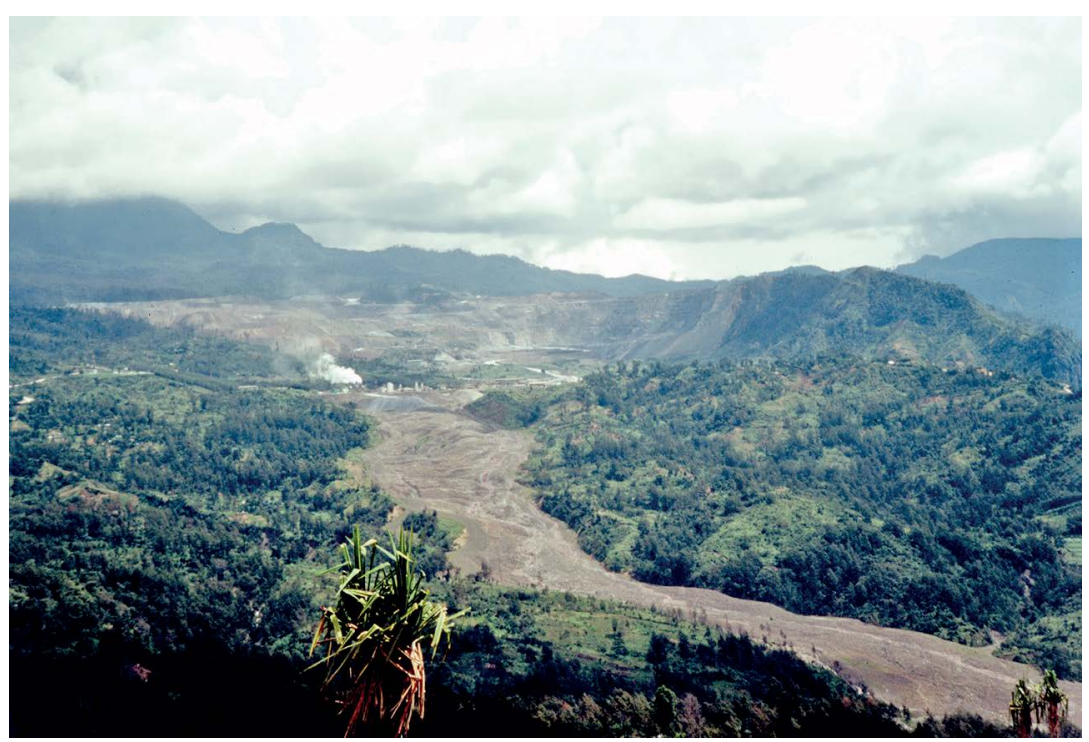

Figure 5.2 The Porgera gold mine.

Source: Photo by the author.

In the following sections, I first describe the ethnographic setting, then focus on the importance of water in Porgeran cosmology. Next I discuss the sociality of rivers, addressing how rivers are not only borders between social groups, but are also used to depict the personal networks that cognatic kinship creates. I also explore rivers as resources that provide additional benefits to a terrestrially focused subsistence horticultural base. In the final section of the chapter, I examine the impacts of riverine tailings 
disposal on the human and biotic communities downstream from the Porgera mine. My conclusions address the implications of the metabolic rift for Porgeran society.

\section{The Porgera Valley}

The Porgera Valley is home to Ipili-speaking subsistence horticulturalists who numbered just over 5,000 in the early 1980s. Since mining development began, outsiders-especially the more numerous Enga speakers to their east-have poured into the valley seeking job opportunities and improved livelihoods that resource development promises. Many of these migrants were welcomed onto Ipili lands, where they built houses and made gardens, eventually becoming integrated into local clans through marriage and exchange ties. With a population just over 22,000 in the 2000 census, today it is estimated that there are around 50,000 people in the valley. Conflicts over land and the scarcity of firewood and building materials are common. Monetary payments in the form of mining royalties and compensation for riverine pollution are another source of frequent outbreaks of violence. Porgeran society is bifurcated between the 'landowning' clans that receive mining benefits due to their lands being within the boundaries of the special mining lease and the much larger numbers of 'non-landowners' who suffer the costs of hosting a mine in the valley but receive little in the way of development benefits (Jacka 2001a, 2007, 2015). Aletta Biersack (2006) has already described the political struggles associated with riverine pollution between landowners, non-landowners and the Porgera Joint Venture (PJV), which operates the mine. In this chapter, I build on her analysis to examine the cosmological impacts of riverine pollution and also to explore some of the ecological and social consequences of riverine degradation.

In Porgera, it is hard to get away from the sound of rushing water. Annually, over 3,700 $\mathrm{mm}$ of rain falls upon the mountainous landscape, turning rushing streams into roaring, boulder-choked rivers further downstream. Geologically, Porgera is comprised of a limestone matrix interbedded with layers of mudstones and siltstones. Due to the porous nature of the limestone, several waterfalls gush from holes midway down the steep cliffs that form the valley's mountainous southern border. Elsewhere in the high-altitude limestone karst country above these mountains, entire rivers disappear into sinkholes only to emerge kilometres away from whence they vanished. Consequently, Porgerans envision the landscape as riddled 
with tunnels through which it is not only water but also ancestral and nature spirits that move. In fact, in order to talk about water and rivers in Porgera, it is necessary to also talk about spirits and the roles they play in regulating water and environmental productivity.

\section{The Cosmology of Water}

There is a fundamental distinction in Porgeran thought between wetness and dryness. In general, wetness and its associated qualities are considered to be a normal or natural state of things, while dryness is a sign of sickness, old age or infertility. Traditionally, collective male bachelor fertility cults and individual female maturation practices used water in order to grow young people into marriageable, fertile adults (Biersack 1998a, 2004). Water, in both of its manifestations as rain and rivers, is embedded in ideas about spirits, the need for moral behaviour in regard to spirits, and moral breaches of reciprocity as likely to result in worldending calamities. In such a mountainous region, the destructive capacity of water is a common topic of conversation due to the numerous raininduced landslides and the torrential rains that swell the waterways and erode adjacent gardens. Yet water is also recognised for its creative abilities to heal, promote growth and combat desiccation and dryness, which are symptoms of human illness and ecological decline. Water is also an important metaphor in that its flow is conceptually believed to ritually link together diverse cultural groups across the PNG highlands (Goldman and Ballard 1998).

Cosmologically, water has the capacity to bestow immortality. Engans (Wiessner and Tumu 1998), Hulis (Ballard 1998; Wardlow 2006) and Porgerans all recite a story about a missed opportunity for immortality when the first baby was born. Piyapa Inguni of Wailya recited the story as follows:

There is a mountain near Mulitaka that has no trees on it; it is only covered with grass. It is called Mt Mungalo. Long ago, there was a woman on Mt Mungalo and she had just given birth. Her husband told her that he was going to go and get water for the baby from a sacred lake [ipa tawe]. He told his wife that if the baby cried she couldn't give it breast milk; she had to wait until he returned with the water. While the man was gone, the baby cried and cried and cried. Finally, the woman let the baby drink from her breast. Then from afar the man cried out, Atambiape? ['Live?']. He heard nothing, so he yelled out, Umambiape? ['Die?']. The woman 
responded affirmatively, Uuuu. When she responded to umambiape, he dumped the sacred water on the ground. Atambiape is the same message that is inside the Bible or that the government tells us; it means we can't fight or get cross. Umambiape has to do with fighting and killing, and we followed this path. If the baby had drunk the water, we would live forever. Since it drank the milk, we are all mortal.

Water, since it comes from the sky people, ${ }^{2}$ and as a one-time potential source of immortality, has the power to wash away sickness and restore health. As described at the beginning of this chapter, Jonah's immersion into the cold waterfall reflects this belief in the curative powers of water. Water is not just important for humans, but figures critically in key ideas about Porgeran ecology. A key principle in Porgeran ecological understanding centres around the idea that human and spiritual activities and environmental processes facilitate the movement of a vital life force called ipane (literally 'grease') through people, plants, animals and the land. The word ipane is comprised of two morphemes, ipa ('water') and ne ('like'), which suggests that grease is something 'like water'. Just as rivers flow across the landscape, disappear into sinkholes and move through the land to reappear elsewhere, ipane flows through the land into plants, into humans and animals that consume those plants, and then is released back into the land when animals are sacrificed and people die. One of the main purposes of ipane is to replenish people, plants and land that are perceived to be otherwise dry.

In several publications, Aletta Biersack (1995, 1998b, 2005, 2011) has argued that human life for the Ipili is governed by a 'sacrificial principle'. What she means by this is that the maintenance and reproduction of human life depletes a person's life force. Gardening, hunting, childbirth, economic exchange, rearing children and so forth exhaust a person to the point that death is inevitable. While most of us are aware of this at a subconscious level, for Ipili speakers it is a central preoccupation. Children are literally said to 'take the place' (panda mia) of their parents (Biersack 2011: 230). The principle of a life for a life is also central to healing rituals in which pigs are killed for sick people, and to the logic of warfare and revenge killings whereby deaths are compensated through payments of pigs.

2 Ipa tawe literally means 'sky water', and refers to small high-altitude lakes associated with the 'sky people'. 
The signs that someone has spent their life in toil under the sacrificial principle are manifested in a person's outward appearance. Wrinkles, white hair and loss of vitality are all indicators of ageing, but also indicate that people have depleted their ipane through the work of production and reproduction. Two vital life fluids, breast milk and semen, contain ipane: breast milk is called andu ipane ('breast grease'), while semen is called $u i$ ipane ('penis grease'). By producing children, parents gradually diminish their own life force. Agricultural activities also involve the flow and transfer of grease, since all land is considered to contain varying amounts of $y u$ ipane ('ground grease'). Over time, as the land is cultivated, a garden eventually loses its grease, resulting in a new garden being planted where there is more grease. Over even longer periods of time, there is a general consensus that the grease has been exhausted from the entire region, and ritual activities of varying intensity, involving one or more social groups, are required to revitalise the world.

Pools of still (immobile and unhealthy) water are thought to contain various spirits that affect Porgerans. Every clan has a sacred pool inhabited by the spirits of deceased ancestors in the high-altitude rainforest above the hamlets. The pools are called ipa ne, ${ }^{3}$ literally meaning 'the water that eats'. Traditionally, illnesses were (and sometimes still are) believed to be caused by deceased clan ancestors. Various rituals were performed to feed the ancestors, by offering them 'food' in the form of the aromas of cooked meat or the blood of pigs poured into the ground, or by the actual delivery of meat to the pools themselves. In the case of the latter, multiple informants describe the water in the pool rising up to snatch the bundle of meat off a long pole that ritual supplicants held over the water. Today, attitudes about these pools are varied. I have previously described a longabandoned ceremony called a kolo that was held in 1999 by the Paiam clan on the site of the Paiam supermarket (Jacka 2001b). The building of the supermarket had destroyed the Paiam clan's sacred pool, and when food and drinks were mysteriously disappearing from the supermarket, the Paiam held a kolo to placate their angered ancestors. On another occasion, after a group of young men took me to see the Pakoa clan's sacred pool, I awoke in one of their houses the following day with my firstever migraine headache, which everyone attributed to us having disturbed the clan's ancestors. Nevertheless, a few months later, I accompanied my

3 Not to be confused with ipane ('grease') since the words are pronounced with different stress on the syllables: I-pa NE versus i-PA-ne. 
research assistant Ben and his father Pes to the site of the Tokoyela clan's sacred pool. It had long since silted over, and Pes nonchalantly walked all over the grassy surface of the former pool, chopping at the grass with his bush knife while telling me about how afraid they used to be of this area because of the ancestral spirits (see Figure 5.3).

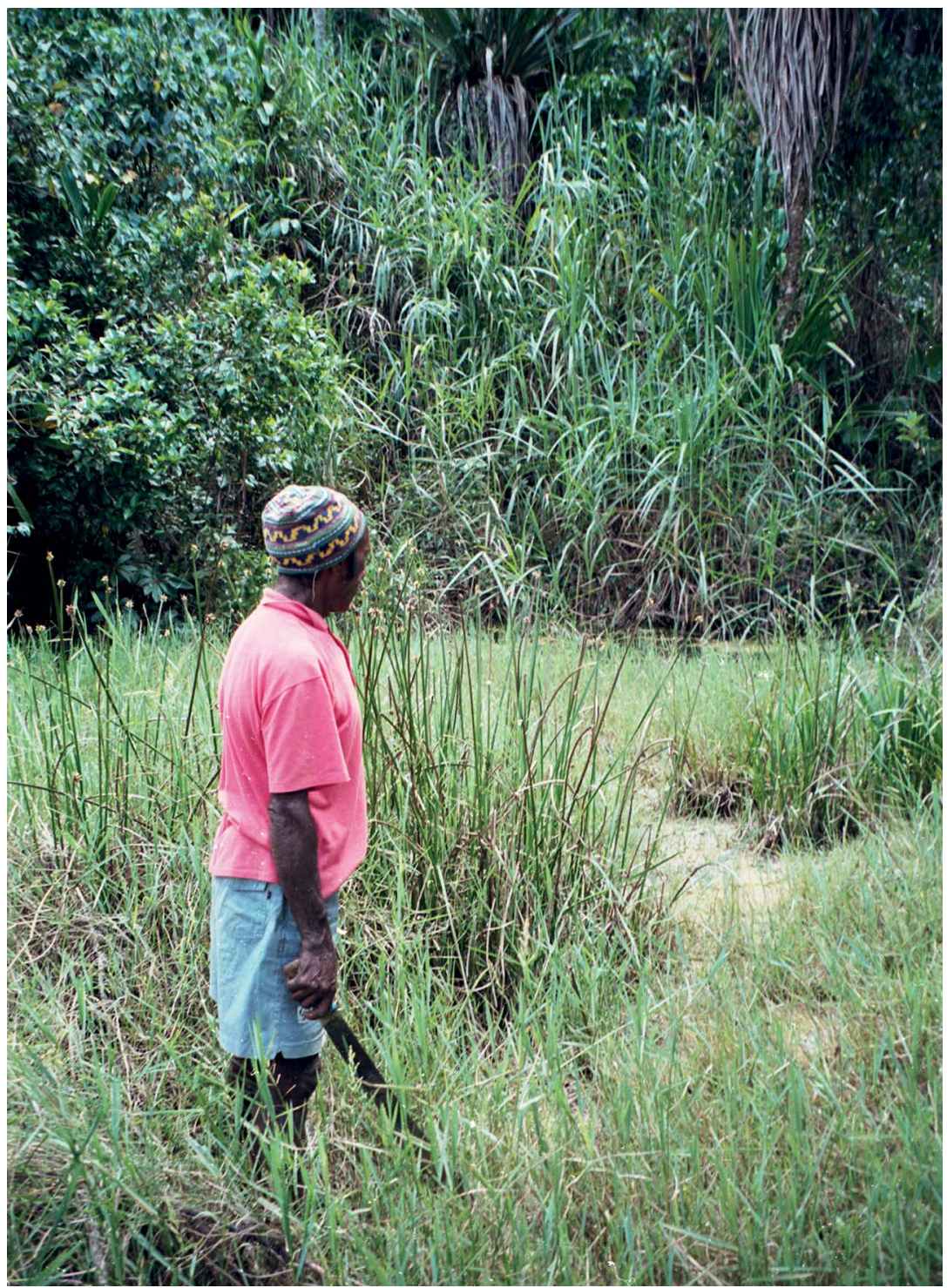

Figure 5.3 Pes Bope at the Tokoyela ipa ne.

Source: Photo by the author. 
Other pools in the high rainforest were also held to contain powerful forces. These pools were associated with sky women (tawe wanda) who had a mythical power to transform boys into powerful men. In all of the myths, a small good-for-nothing younger brother is shunned by his older brothers. After being cast out of the house, he wanders the high rainforest until he runs into a beautiful woman. She takes the young boy and coaxes him under the water. When he re-emerges, he has been transformed into a tall, muscle-bound warrior. The sky woman then plies him with pigs, shell wealth and resplendent bodily ornamentations like bird of paradise headdresses, marsupial fur headbands and woven cane armbands. Thus transformed, the younger brother returns to his hamlet, where he is desired by all of the young women and envied by his brothers. A number of male puberty ceremonies among the Ipili and Enga attempted to ritually unite participants with a sky woman in order to bring about these positive transformations encoded in myth (Meggitt 1964; Biersack 1998a, 2004; Wiessner and Tumu 1998).

Tawe wanda also play beneficial roles in human affairs. Biersack's (1982, 1998a, 2001, 2004) writings on the beautification of young people of both sexes show that the sky women are largely responsible for 'growing' adolescent males into marriageable and sexually active adults. Growth in general is thought to occur through female agency. Pregnancy also associates women with bodily growth. Additionally, while men cut and fence gardens, women plant and tend the crops and thus 'grow' the gardens. Growth does not occur naturally, but 'transactionally, as the beneficiary of someone's action' (Biersack 1982: 241, emphasis removed). Through proper observance of menstrual taboos, wives help grow their husbands' skin by depositing their menstrual wastes at the base of tato (southern beech or Nothofagus) trees, which are the only trees considered strong enough to withstand the powerful influences of menstrual blood. During puberty rituals, young bachelors 'married' tawe wanda who were then responsible for 'growing' them into marriageable adults. While there were no equivalent rituals for young women, they did go out into secluded spots in the residential area in the mornings and shake dew onto their skin, which was said to grow their skin, breasts and hair in anticipation of marriage and motherhood. ${ }^{4}$ Dew, rain and lightning are all associated with sky people. Among the Enga, sky women are said to cause rain, sprinkling water from a lake located in the sky (Talyaga 1982: 67).

4 See Biersack (1998b) for a full description of young women's growth rituals. 
While water has the power to heal sickness and cause maturation, there are also malevolent forces associated with rivers and pools. Trickster spirits called ipa titi ('water fools') live in the rivers (see Goldman 1998). Generally, these spirits are merely mischievous, and will hide people's axes or spades while they are resting from gardening work, but occasionally they are more dangerous. When women are planting sweet potatoes, they hang their infants in net bags from tree limbs next to where they are working to keep them close but out of harm's way. If this is done too close to a stream or river, ipa titi will sometimes swap their own babies with the human babies. Children that are physically deformed or mentally challenged are said to be the products of such transfers. As a result, Porgerans prefer not to make gardens adjacent to streams and rivers, which has the added ecological benefit of reducing erosion and sedimentation in the rivers.

As seen in this and the previous section, water serves as a critical feature through which to observe the interface of human and spiritual worlds in Porgera. Water is the medium through which humans interact with spirits, and water as both precipitation and in the flow of rivers provides evidence of spiritual forces acting upon the land. In the next section of this chapter, I turn away from spirits and the cosmology of water to examine some of the ways that water defines sociality in the area.

\section{The Sociality of Rivers}

Rivers, like mountain ranges, are borders that separate social and ethnolinguistic groups in PNG (Weiner 1991; Feld 1996; also Wagner, this volume), while major streams often function as boundaries between clans. The Wateya River, introduced at the beginning of the chapter, is the border between the Tokoyela and Yomondaka clans; however, in songs and oral literature, Wateya is a metaphorical way of referring to someone from either of these clans. The Wateya River is both a symbol of the separateness of two different social groups and a symbol of their shared involvement with that waterway. Rivers, therefore, both separate and unify social groups (see Feld 1996).

The first funeral I attended in Porgera was of a woman, Tapiama, who died unexpectedly in her middle to late 40s. She was one of Samson Kaiyama's 'aunties', and he came by my house early one morning to see if I wanted to attend her funeral with him. I accompanied Samson, absolutely uncertain of what to expect. We walked for about an hour along a rough track 
through forests and gardens to Lese, the main hamlet of the Pakoa clan. As we climbed up to the cleared space in the centre of the hamlet in which all social functions take place, we could hear the wailing and crying of mourners. Samson burst into a rhythmic wailing that matched that of the other mourners, and went and joined the group of people huddled around Tapiama's open casket. I joined the crowd of several dozen onlookers who conventionally sit in the grass around the main mourners and support them by their presence at the funeral.

After 15 minutes or so, Samson joined me. Samson was one of my closest neighbours in Kolatika, as his sub-clan, the Tokoyela-Pinawi, had donated the land my house was built on to the district authorities for development purposes. A few minutes after Samson sat down, Tapiama’s oldest daughter, a woman in her 20s, began to wail and sing a song while holding her mother's head between her hands. Samson urged me to record the song and said that we would talk about it later. Later that afternoon, back in my house, Samson and I listened to the recording. This is a translation of the song:

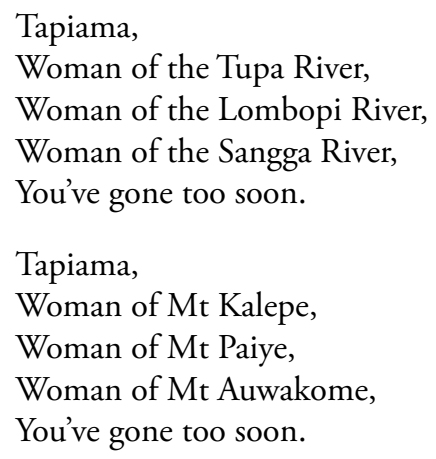

Tapiama's daughter repeated these verses over and over, occasionally adding a new river or mountain to her mourning song. Samson explained the significance of these place names to me, noting that the Tupa, Lombopi and Sangga rivers were boundaries between the Pakoa clan and the Nomali, Yawanakali and Lake clans respectively. Tapiama's funeral had been attended by Nomali, Yawanakali and Lake people with whom she shared kinship relations. Mt Kalepe was a metonym used specifically to refer to the Tokoyela clan whose members were also Tapiama's kin. Paiye and Auwakome are the mountains of the Pakoa people. In essence, what Tapiama's daughter's mourning song had signified was that, despite clans in Porgera being associated with particular landholdings, people's 
paths through life, both through their everyday practices and through their kinship linkages, are defined by the rivers and mountains that both separate and unify social groups. Her mourning song wove together the places and people that were instrumental in Tapiama's identity as a social being.

Major rivers are also used in the Porgera area to express oppositional identities (see Silverman, this volume). Porgerans define themselves in opposition to the Hewa people, living north of the Lagaip River, whom they characterise as demons and cannibals in stories. In one story about the origins of agriculture, Tisapa Yawe tells of the first woman 'who had no parents or kin and was the mother of all Porgerans' and only ate wild plants and the leaves of trees. She lived at the mouth of the Porgera River, and one night a torrential rainstorm flooded the river. In the morning, she found all of the domesticated plants that Porgerans eat today-sweet potatoes, taro, greens-and an axe. She tasted the foods and found them delicious so she cut a garden out of the forest. Afterwards, she planted pandanus trees all along the south banks of the Lagaip River to mark the border between her place and the land of the Hewa.

Another example of rivers expressing oppositional identities comes from a myth about an ancient battle between the Keta River and the Lagaip River, in which the Lagaip pushed the Keta into its present-day watershed (see Figure 5.1). The Keta River is the homeland of a number of Western Enga clans who are traditional enemies of Eastern Porgeran clans. In 1988, a tribal fight broke out between two Eastern Porgeran clans. The Undiki called upon some of their Western Engan allies to come and support them in the fight, which they did. The Tokoyela tried to find some allies in Porgera to assist them, but as this was a period of time in which a gold rush was occurring at nearby Mt Kare, and mining development was already underway at Porgera, few clans were willing to get involved in the conflict. However, later that year, a Western Engan man who was an ally of the Undiki was heard boasting that the Keta River was going to wipe out the Porgera River in this tribal fight. Invoking this myth in this manner, and reinterpreting it to represent contemporary ethnic opposition between Porgerans and Engans, upset several of the Eastern Porgeran clans who had remained neutral. As a consequence, they joined the Tokoyela and defeated the Undiki, driving most of them into the Western Enga area and out of the Porgera Valley. 


\section{Rivers as Resources}

If rivers are important cultural, historical, symbolic and social markers in this area of the PNG highlands, what about their practical and everyday uses?

I never saw a Porgeran drink from a river. People are unsure of what others upstream may have done to or in the water. When people slaughter pigs, women take the intestines to the river and wash them out in the water; people bathe and wash their clothes in the rivers; some households use them as toilets and, as a consequence, people are unwilling to drink river water (see Figure 5.4). Springs serve as the sources of drinking water, and scattered throughout the valley are cliff faces where someone has shoved a pandanus leaf or bamboo tube into a spring, allowing a trickle of water to be directed into drinking gourds and plastic bottles.

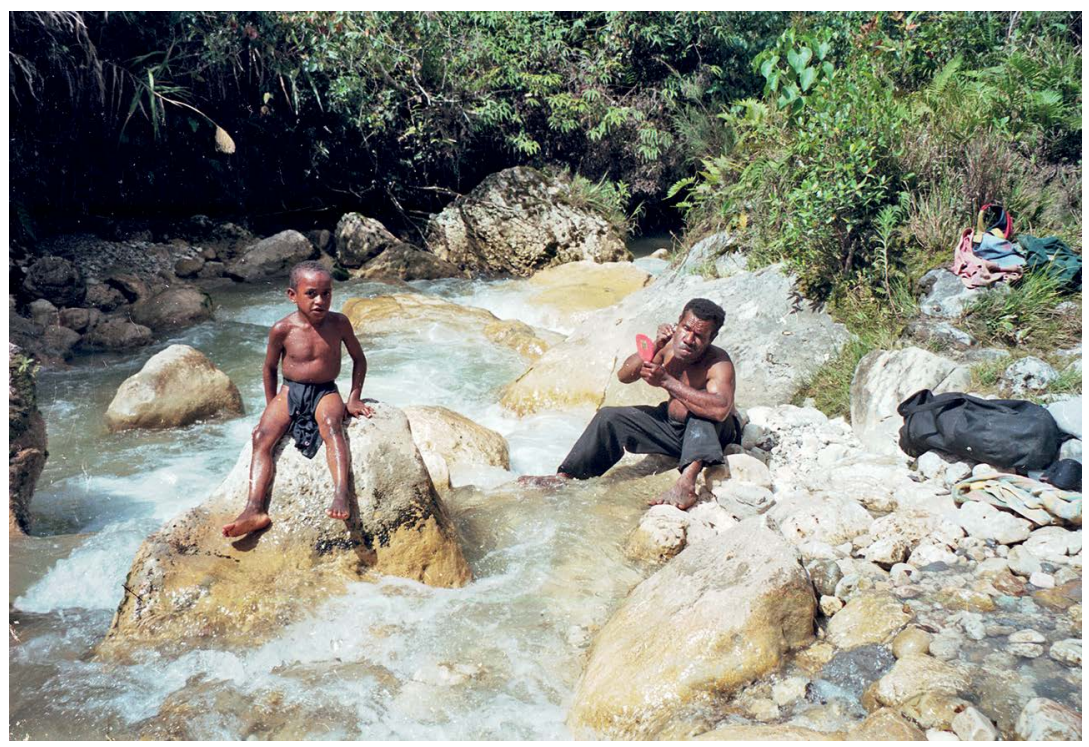

Figure 5.4 Bathing in the Wateya River.

Source: Photo by the author.

Traditionally, there were few aquatic resources that people gathered. The main ones were frogs and eels. Pes Bope recalls the times that his mother would gather frogs: 
I would often go out and gather pitpit (Miscanthus floridulus) for my mother to make torches so that she could catch frogs. Catching frogs and birds at night was women's work. When I went out in the day to get pitpit, no one could see me. If they saw me they would know what was going on and send yama au [a type of illness]. So I hid and filled the house full of dried pitpit. My mother would come home from the garden and be really happy because she could go frog catching. In the afternoon she would take the pitpit down to the edge of the Tupa River. While waiting there for the sun to go down she would cook some food and eat. She would start bundling the pitpit together for torches. Once the sun went down and it got dark, she would light a torch and start catching frogs. They would be on the tree branches, rocks, next to the river, on the ground. She'd catch kambupara, wa, kiyakonge, angimonge, doyane, karakara, pandamonge, and kapamu [all different frog species]. Sometimes snakes too. She'd be out there all night catching frogs. Just before sunrise she'd come home. Whenever she knocked at the door I was always so excited. I'd ask her what she caught. She always said, 'Oh, I didn't get anything.' I'd hug her and ask, 'Mom, Mom, did you get any frogs?' She'd come in and her bilum [net bag] would be close to bursting with frogs. She'd take the bilum down and distribute frogs to everyone in the house. We'd take our share and wrap it in ferns and then we'd take it to the pombata anda. This means 'house of the grubs'. Anything that had meat-grubs, pig, frogs, marsupials, birds-we'd mumu [cook in an earth oven] in these pombata anda houses.

Pes's narrative highlights the importance of meat in local diets. The illness called yama au is very similar to another illness called uyenda. Whereas uyenda requires someone to see you eating something, yama au can be sent by someone merely thinking of the fact that you are getting ready to eat meat. Yama au is also much deadlier than uyenda, and hunters use magic to block yama au that people from the hamlets send to them while thinking about what the hunters are eating in the forest. Loosely translated, yama au means something like 'spirit carried', and since the illness is caused by a spirit (yama) it is more difficult to treat than uyenda, which is physiological.

Prior to the mid-twentieth century, fish (other than eels) were not part of the Porgeran diet. Rainbow trout (Oncorhynchus mykiss) were introduced into various highland waterways in the mid-twentieth century, both by private parties and the Australian colonial government. By 1992, there was a stock of 10,000 fingerlings in the reservoir of the Waile Creek dam 
in Porgera, and rainbow trout are now in all of the main waterways in the area. Trout fishing in Porgera is currently a cross between a pastime and a subsistence activity undertaken by boys and young men. ${ }^{5}$

Today, few people rely on the rivers for any subsistence activities. I am uncertain whether this is due to the exotic trout and/or mining wastes decimating the population of native frogs and eels in the Porgera River, or whether they are no longer gathered because of the abundance of tinned fish available in the trade stores. This of course does not mean that the rivers are no longer important for Porgerans. As detailed thus far in this chapter, water and watercourses are central to Porgeran ideas about ecology, cosmology and sociality. And there was one resource that came from the rivers that was essential to Porgeran livelihoods prior to the era of large-scale mining - the alluvial gold whose deposits came to be called 'second gardens' by most Porgerans.

These deposits were discovered in 1939 and began to be worked in the late 1940s by a few expatriate prospectors who paid Porgeran labourers with shells and steel tools. By the late 1950s, Porgerans had started mining for themselves, and in 1960 the first Indigenous claims were staked (Robinson 1960). Due to cognatic kinship reckoning, the majority of Porgerans were able to demonstrate some sort of affiliation to the claim owners or their clan, allowing them land rights and de facto rights to alluvial gold beds. In the alluvial mining era, before 1990, researchers estimated that as many as 75 per cent of all able-bodied males in the valley spent some time working, or at least had access to, the alluvial gold beds (Handley and Henry 1987).

With the demise of the global gold standard and the subsequent increase in the price of gold, outside interests - transnational mining companies and the PNG state-started seeking new ways to discover and develop Porgera's subterranean gold deposits. By 1987, the PJV had been formed and agreements were signed with the seven 'landowning' clans in regards to royalty payments, compensation for lost land, relocation houses and other development perks (Banks 1999; Filer 1999). During the negotiations for mining development, the PJV had effectively argued against the feasibility

5 A couple of times in 1999 and 2000, I joined Cowboy Kuraia, a young Porgeran man passionate about catching trout, and some others to fish the high headwaters of the Wateya River above Kolatika. We would creep stealthily up to the water with fishing line and hooks baited with sweet potato. Try as we might, none of us, with the exception of Cowboy, caught any fish. Graciously, Cowboy usually let me take some of his fish home to eat as a reward for my efforts. 
of a tailings dam, claiming that the 'abnormally' heavy rainfall and unstable geology would lead to a massive tailings dam failure (Shearman 2001). Instead, the PJV convinced the PNG Government to allow the riverine disposal of tailings and to achieve compliance with water quality standards at a monitoring station $165 \mathrm{~km}$ downstream of the mine! ${ }^{6}$ The clans in Porgera immediately downstream, who had the richest alluvial gold beds, were acutely worried about their ability to continue working in what they had long called their 'second gardens' (Winchomba 1970). Moreover, these clans were not part of the group of landowning clans whose members were going to become the new beneficiaries of hardrock mining. As we shall see, they had every right to be worried.

At this point, I want to take a step back and examine how Porgerans have conceptualised gold as a resource. Significantly, prior to its discovery by Australian patrol officers, they had no use nor word for gold, nor as far as I can tell even any awareness of it. Once its value was realised, however, gold quickly became imbued with a cosmological interpretation. This interpretation was reliant upon the idea of python spirits who moved through and lived in the tunnels believed to underlie the land. Gold is said to be their shed skins. These python spirits also played critical roles in the sacrificial rituals that Porgerans conducted to maintain the fertility of both land and people. ${ }^{7}$ Kupiane, the python spirit associated with the Porgera gold mine, lived in the heart of what used to be Mt Watukati, which is now the centre of the mine pit. Sacrifices to Kupiane by the Tiyeni clan in the past are today interpreted by clan members as initial exchange offerings that Kupiane is now paying back to the Tiyeni, the largest landowning clan, in the form of mining wealth. That numerous other clans in the region also sacrificed to python spirits is strong evidence that the area is rife with as yet undiscovered gold deposits. Some people have also claimed that there is but one python to which everyone was making sacrifices and, by this logic, the mining wealth should be shared much more widely than it currently is.

6 The water quality standards were based on an Environmental Management and Monitoring Program agreed upon by the PNG Government and the PJV. The point of compliance assessment was the third of nine monitoring stations located along the Porgera, Lagaip, Strickland and Fly Rivers and in the Fly River delta.

7 As one man said to me, some people still offer sacrifices to a cave opening while on their way en route to mine for gold at Mt Kare in order to appease the python spirit, Taiyundika, 'just in case'. 
The concentration of wealth among the landowning clans is particularly problematic for the downstream non-landowning clans whose members accrued most of the wealth in the alluvial mining era, especially since development of the large-scale mine has buried the alluvial beds under tons of waste rock and sediments. However, in the mid-1990s, clans that held land alongside the former alluvial beds were compensated for the loss of their income from gold. A one-time lump sum payment was made that has been followed with quarterly payments based upon the actual tonnage of waste and tailings that is put into the Porgera River. Community affairs officers insisted to me that the downstream clans will actually have earned more money this way than if they had been allowed to continue with alluvial mining. This may be so, but what cash payments have done in the hard-rock mining era is to make it easier for those people who receive royalty checks to restrict the network of individuals with whom they share their wealth. More money is coming into the valley, but it is being shared among fewer people-a point that generates considerable social tension between the haves and the have-nots. Water also plays into the way that money from mining is expected to flow. The anthropologist John Burton (2014: 46) recounts a meeting he had with some of the disenfranchised Porgerans where the lack of mining benefits was compared to 'water flowing down a tap, where a person could reasonably expect water to appear. Except ... nothing came out of the tap'.

For the disenfranchised Porgerans living near the former ritual site where pigs were sacrificed to Lemeane in order to maintain the water balance of the land and ensure human and biotic fertility, the ritual site and its linkages have assumed new salience with large-scale mining development and the loss of alluvial mining opportunities. Many of the Porgerans living around the ritual site were quite emphatic that their ritual activities were part of a chain of rituals that linked Lemeane to Kupiane and to ritual sites among the neighbouring Huli and Enga (see Biersack 1998b). Huli speakers living near the ritual site of Tuandaka (Wiessner and Tumu 1998) also claim this interconnection of former ritual activities, and even argued to me that the python at Tuandaka was responsible for the oil and gas fields in the southern part of the Papuan Plateau, now the site of PNG's Liquified Natural Gas Project, as the python's urine turned into petroleum, thus enriching the landowners associated with its development. Of course, the challenge for non-landowners living near these projects is to have their claims recognised by the landowners and be able to share in the resultant resource wealth. In Porgera, thus far, this has 
not happened and, as a consequence, tribal fighting has increased as nonlandowning clans try to extort payments from landowning clans through threats, targeted killings and the burning of government buildings located within the land boundaries of the landowning clans.

\section{The Impacts of Riverine Pollution}

The $165 \mathrm{~km}$ stretch of river from the Porgera mine to the water quality compliance monitoring station is called 'the mixing zone' by the PJV. This mixing zone comprises the entire Porgera River downstream of the mine, the entire lower portion of the Lagaip River from where the Porgera empties into it and the upper portion of the Strickland River. At the confluence of the Strickland and the Fly River, Porgera's mining wastes intermingle with those from the Ok Tedi mine (Kirsch 2006, 2014), and some of the material eventually flows into the Gulf of Papua. Mining companies in PNG have successfully argued for riverine disposal of mining wastes and tailings due to the high sediment loads that naturally occur in PNG's rivers, as well as to the risk that tailings dams will fail. The added inputs that come from mining, they claim, do not significantly alter the pre-mining sediment profiles. A better term for the 'mixing zone' might be 'the sacrifice zone' (Kuletz 1998), given the concentrations of toxic and heavy metals that mining releases, which are not part of naturally occurring sedimentation processes in the country's rivers. Moreover, as Stuart Kirsch (2006) has documented for people living downstream of the Ok Tedi mine, the build-up of mining sediments has caused metalladen waters to kill riverside forests and sago gardens along vast stretches of the river. These riverine mining sacrifice zones impact the livelihoods of thousands, if not tens of thousands, of Papua New Guineans who live and garden along their banks and utilise aquatic resources in their diets.

Following an audit of PJV's waste disposal practices by the (Australian) Commonwealth Scientific and Industrial Research Organisation (CSIRO 1996), conducted in response to a report by environmental science student Phil Shearman (1995), CSIRO recommended that the PJV move their compliance assessment point to the second monitoring station approximately $40 \mathrm{~km}$ downstream from the mine (see Figure 5.5). This was never done, and the third station (SG3) is still the point at which compliance is assessed. Annual reports from SG3 were not published during the years that Placer Dome was the operating partner in the PJV. 
In a classic case of 'green-washing', in lieu of actual data, Placer published an annual series of 'sustainability' brochures-glossy, magazine-like documents that demonstrated all of the good corporate social practices that the PJV was engaged in among the affected communities (see Burton 2014). After the acquisition of Placer Dome by Barrick Gold in 2006, the sustainability brochures were replaced with detailed reports, several hundred pages in length, illustrating the levels of heavy metals and other measures from the various monitoring stations, and rife with charts, statistics and other details beyond the comprehension of most rural Papua New Guineans. Whereas Placer Dome's technique of greenwashing glossed over the impacts of riverine pollution, Barrick's version of transparency buries villagers in paper piles of mining waste documentation in a metaphorical analogue of the mining waste piles burying their lands and rivers. Both corporate strategies fail to provide accessible information to communities impacted by mining activities.

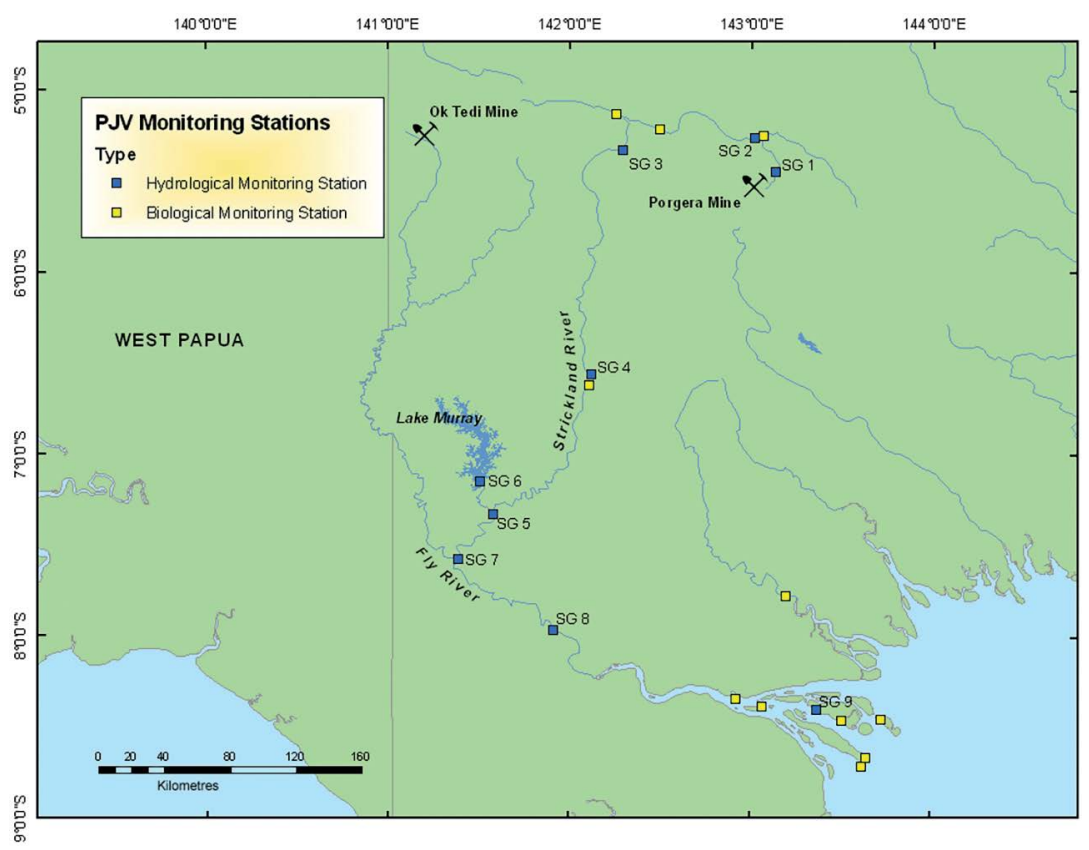

Figure 5.5 PJV monitoring stations.

Note: SG3 is $165 \mathrm{~km}$ downstream from the mine.

Source: Created by the author. 
In 1998, following receipt of the 1996 CSIRO report, the PJV instituted what was meant to be an independent advisory body, called the Porgera Environmental Advisory Komiti ('Committee') or PEAK, to monitor the mine's impact on the physical and social environment (see Burton 2014). ${ }^{8}$ In 2008, the PEAK decided to start issuing annual report cards on the conditions of the various river systems impacted by the Porgera mine. The data were divided into five groups of indicators: dissolved metals; metals in sediments; other water quality parameters, such as conductivity, total suspended solids, $\mathrm{pH}$ and cyanide; metals in fish tissues; and fish biomass. Each of these divisions was then scored as 'green-below level of concern'; 'yellow-moderate level of concern'; and 'amber-high level of concern'. The 2009 report card for the upper river at SG1 in the Porgera Valley had high levels of concern for three of the five indicators: dissolved metals; metals in sediment; and other water quality parameters. There were no data for the other two indicators. SG3, the compliance assessment point, was below level of concern for dissolved metals, had a moderate level of concern for metals in sediments and other water quality parameters, and no data for the fish indicators.

Over the years, I have received reports from local people that pigs, wildlife and humans had died after coming into contact with the water in the Porgera River (see also Biersack 2006). Penny Johnson's (2011) research on women in Porgera found that women from the villages adjacent to the mine were not only afraid to use river water for fear of the pollutants believed to be in it, but also referred to rain as "acid rain" and the root of many illnesses in the community' (Johnson 2011: 29). Not only do people worry about the pollutants in the river; the colour of the water is also alarming from a cultural perspective. Dissolved iron oxides that result from the processing and disposal of the mining wastes have turned the Porgera River bright red on most days (see Figure 5.6). For Porgerans, 'the

8 PEAK's 'independence' from the PJV was contentious throughout its duration. In 2001, its chair Yati Bun resigned, writing: 'My conscience cannot tolerate being involved any longer with the PEAK process of expediting the continuation of riverine discharge, as when the history of Porgera is written I do not wish to be the one that oversaw Porgera's impacts and did nothing. My resolution to leave PEAK was further galvanized when I saw how my name and involvement in PEAK [was] being used in propaganda materials ...' (PEAK Minutes, October 2001). Also starting in 2001, meetings were moved from Porgera to PJV's corporate headquarters in Port Moresby. In meeting minutes from 2004, committee members worried that PEAK did not appear to be at 'arms length' from PJV, noting that 'an overly demanding watchdog might lead to PJV reluctance to provide information' (PEAK Minutes, October 2004). Following a series of investigations of human rights violations at Porgera in the early 2010s, the PEAK website was taken down and the organisation was dissolved (Philip Gibbs, former committee member, personal communication, 26 August 2017). 
colour red carries a heavy symbolic load' linking the river to 'menstrual blood, which men find threatening and women find disgusting', making the river 'noxious to local sensibilities' (Biersack 2006: 233-4). Men fear menstrual blood for its abilities to 'block' a man's urethra if he inadvertently eats food that a menstruating woman has prepared or if he has intercourse with a menstruating woman. If not cured, men are said to die from this affliction. What does it mean then for a river to be perceived as a menstrual flow?

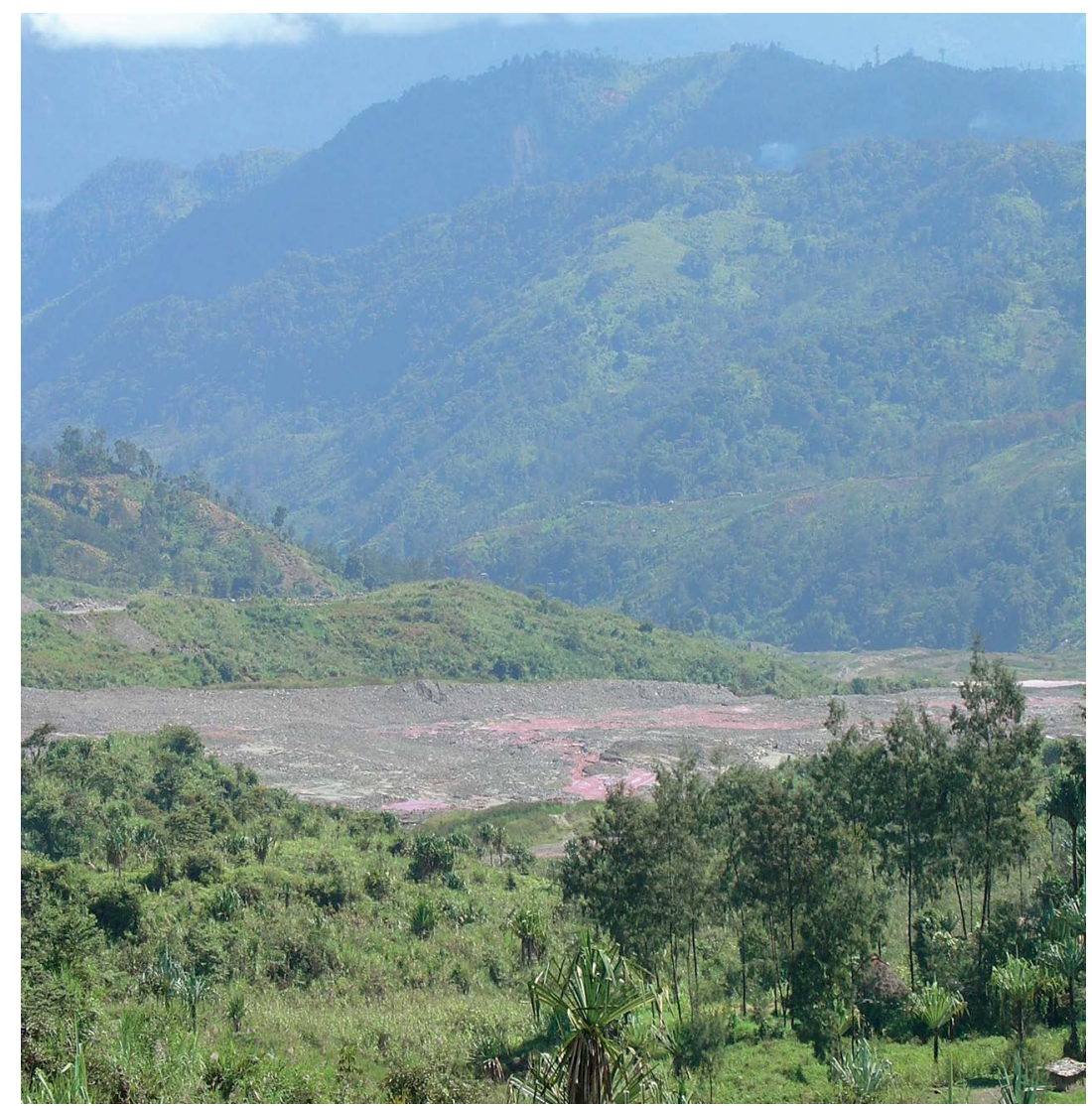

Figure 5.6 The Porgera River flowing down the 'glacier' of waste rock. Source: Photo by the author.

Recall that the very fertility of the earth depends on the maintenance of 'grease' (ipane) in the land. Production and reproduction-garden labour, sexual intercourse, breast feeding, menstruation-all deplete the ipane in human bodies. People say that mining depletes the ipane 
in the land. A turn of phrase that Porgerans frequently use to comment on the impacts of mining is to say that 'the land is ending' ( $y u$ koyo peya). The gaping maw of the open pit mine eating away the land-the very resource base of Porgera's horticultural society-and the blood-red flow of the polluted Porgera River seeping out of the open gash in the land are visceral reminders to Porgerans of the costs and consequences of hosting a world-class mine on their lands.

The Porgera River thus serves as a blood-red reminder of the 'metabolic rift' and the ways that capitalist expansion tears asunder local livelihoods and ecologies. Marx (1990) used the German word stoffwechsel ('material exchange') to describe the metabolic processes that occur between humans and nature. What Marx was referring to was the environment as the source of food, clothing and shelter for humans, and humans as caretakers of the environment to ensure the continuing production and reproduction of both people and nature. According to Marx, large-scale capitalist production creates an irreparable rift between humans and nature because it 'disturbs the metabolic interaction between [humans] and the earth' by 'robbing' the earth of 'its constituent elements' (Foster 2000: 155-6). Not only does it rob the earth of its constituent elements; it robs the very people whose livelihoods are dependent upon the intricate social, mythological and material relations they have fostered with their environments.

\section{Conclusion}

My goal in this chapter has been to consider mining development impacts on the Porgera River in a holistic sense from the perspectives of Porgerans. When Porgerans discuss the ruination of the river, there is more at stake than just the loss of fish and frogs and the fouling of the water. The very riverbeds were dug out by the actions of ancestral hero figures that were also responsible for controlling the water balance in the land and the fertility therein. Water itself is fundamental to Porgeran ideas of cosmology and well-being. For close to 50 years, the alluvial gold resources were the second gardens that provided livelihood benefits and cash incomes in a society that was just then being integrated into the global economic system. Foreign investment and loss of control over the gold resources resonate throughout Porgeran society today in the form of often violent political clashes over the restricted benefit streams available to a minority of people in the valley. 
The island of New Guinea is the only place on the planet where multinational mining companies practice riverine tailings disposal (Vogt 2012). The Porgera, Ok Tedi and Tolukuma mines in PNG, and the Grasberg mine in West Papua, all dispose of tailings that detrimentally impact the riverine environments downstream from their discharge points. In all of these cases, the mining companies were successfully able to argue that the unique geological and climatic conditions of New Guinea made riverine tailings disposal the only feasible method for tailings treatment. Given these facts, this begs the obvious question: Should mining be conducted in its current form on the island of New Guinea? The island is one of what Conservation International designates as the planet's five 'high biodiversity wilderness areas' (Mittermeier et al. 2003). It is also home to approximately one-sixth of the world's linguistic and cultural diversity. The ever-expanding growth of capitalist resource extraction promises to acutely degrade this incredible cultural and biological diversity.

\section{Acknowledgments}

Funding was provided by the Wenner-Gren Foundation for Anthropological Research and the National Science Foundation. Research permission was granted by PNG's National Research Institute. As always, my greatest appreciation goes to the people of the Porgera Valley. Ben Penale, Peter Muyu and Epe Des have helped my research in innumerable ways and I am eternally grateful for all they have done for me.

\section{References}

Ballard, C., 1998. 'The Sun by Night: Huli Moral Topography and Myths of a Time of Darkness.' In L.R. Goldman and C. Ballard (eds), Fluid Ontologies: Myth, Ritual and Philosophy in the Highlands of Papua New Guinea. Westport (CT): Bergin \& Garvey.

Banks, G., 1999. 'The Economic Impact of the Mine.' In C. Filer (ed.), Dilemmas of Development: The Social and Economic Impact of the Porgera Gold Mine, 1989-1994. Canberra: Asia Pacific Press.

Banks, G., D. Kuir-Ayius, D. Kombako and B. Sagir, 2013. 'Conceptualizing Mining Impacts, Livelihoods and Corporate Community Development in Melanesia.' Community Development Journal 48: 484-500. doi.org/10.1093/ cdj/bst025 
Beck, U., 1992. Risk Society: Towards a New Modernity (transl. M. Ritter). London: Sage Publications.

Biersack, A., 1982. 'Ginger Gardens for the Ginger Woman: Rites and Passages in a Melanesian Society.' Man (NS) 17: 239-258. doi.org/10.2307/2801811

_ 1995. 'Heterosexual Meanings: Society, Economy, and Gender among Ipilis.' In A. Biersack (ed.), Papuan Borderlands: Huli, Duna, and Ipili Perspectives on the Papua New Guinea Highlands. Ann Arbor: University of Michigan Press.

_ 1998a. 'Horticulture and Hierarchy: The Youthful Beautification of the Body in the Paiela and Porgera Valleys.' In G. Herdt and S. Leavitt (eds), Adolescence in Pacific Island Societies. Pittsburgh: University of Pittsburgh Press.

, 1998b. 'Sacrifice and Regeneration among Ipilis: The View from Tipinini.' In L.R. Goldman and C. Ballard (eds), Fluid Ontologies: Myth, Ritual and Philosophy in the Highlands of Papua New Guinea. Westport (CT): Bergin \& Garvey.

_ , 2001. 'Reproducing Inequality: The Gender Politics of Male Cults in Melanesia and Amazonia.' In T. Gregor and D. Tuzin (eds), Gender in Amazonia and Melanesia: An Exploration of the Comparative Method. Berkeley: University of California Press. doi.org/10.1525/california/9780520228511.001.0001

, 2004. 'The Bachelors and Their Spirit Wife: Interpreting the Omatisia Ritual of Porgera and Paiela.' In P. Bonnemere (ed.), Women as Unseen Characters: Male Ritual in Papua New Guinea. Philadelphia: University of Pennsylvania Press.

— , 2005. 'On the Life and Times of the Ipili Imagination.' In J. Robbins and H. Wardlow (eds), The Making of Global and Local Modernities in Melanesia: Humiliation, Transformation and the Nature of Cultural Change. Burlington (VT): Ashgate.

_ , 2006. 'Red River, Green War: The Politics of Nature along the Porgera River.' In A. Biersack and J.B. Greenberg (eds), Reimagining Political Ecology. Durham (NC): Duke University Press. doi.org/10.1215/ 9780822388142-009

__ 2011. 'The Sun and the Shakers, Again: Enga, Ipili, and Somaip Perspectives on the Cult of Ain, Part Two.' Oceania 81: 225-243.

Burton, J., 2014. 'Agency and the "Avatar" Narrative at the Porgera Gold Mine, Papua New Guinea.' Journal de la Société des Océanistes 138/139: 37-51. doi.org/10.4000/jso.7118 
CSIRO (Commonwealth Scientific and Industrial Research Organisation), 1996. Review of Riverine Impacts: Porgera Joint Venture. Canberra: CSIRO Environmental Projects Office.

Feld, S., 1996. 'Waterfalls of Song: An Acoustemology of Place Resounding in Bosavi, Papua New Guinea.' In S. Feld and K. Basso (eds), Senses of Place. Santa Fe (NM): School of American Research Press.

Filer, C. (ed), 1999. Dilemmas of Development: The Social and Economic Impact of the Porgera Gold Mine, 1989-1994. Canberra: Asia Pacific Press.

Foster, J.B., 2000. Marx's Ecology: Materialism and Nature. New York: Monthly Review Press.

Goldman, L., 1998. 'A Trickster for All Seasons: The Huli Iba Tiri.' In L.R. Goldman and C. Ballard (eds), Fluid Ontologies: Myth, Ritual and Philosophy in the Highlands of Papua New Guinea. Westport (CT): Bergin \& Garvey.

Goldman, L.R. and C. Ballard (eds), 1998. Fluid Ontologies: Myth, Ritual and Philosophy in the Highlands of Papua New Guinea. Westport (CT): Bergin \& Garvey.

Handley, G. and D. Henry, 1987. 'Porgera Environmental Plan: Report on Small Scale Alluvial Mining.' Porgera District Administration archives (unpublished manuscript).

Jacka, J.K., 2001a. 'On the Outside Looking In: Attitudes and Responses of Non-Landowners towards Mining at Porgera.' In B. Imbun and P. McGavin (eds), Mining in Papua New Guinea: Analysis and Policy Implications. Port Moresby: University of Papua New Guinea Press.

- 2001b. 'Coca-Cola and Kolo: Land, Ancestors, and Development.' Anthropology Today 17(4): 3-8. doi.org/10.1111/1467-8322.00068

—, 2007. 'Whitemen, the Ipili and the City of Gold: A History of the Politics of Race and Development in Highlands New Guinea.' Ethnohistory 54: 445-471. doi.org/10.1215/00141801-2007-003

- 2015. Alchemy in the Rain Forest: Politics, Ecology, and Resilience in a New Guinea Mining Area. Durham (NC): Duke University Press.

Johnson, P., 2011. 'Scoping Project: Social Impact of the Mining Project on Women in the Porgera Area.' Port Moresby: Porgera Environmental Advisory Komiti. 
Kirsch, S., 2006. Reverse Anthropology: Indigenous Analysis of Social and Environmental Relations in New Guinea. Stanford (CA): Stanford University Press.

— 2014. Mining Capitalism: The Relationship between Corporations and their Critics. Berkeley: University of California Press.

Kuletz, V., 1998. The Tainted Desert: Environmental and Social Ruin in the American West. New York: Routledge.

Marx, K., 1973. Grundrisse: Foundations of the Critique of Political Economy (transl. M. Nicolaus). New York: Random House.

_ - 1990. Capital: A Critique of Political Economy, Vol. 1 (transl. B. Fowkes). London: Penguin Classics.

May, R.J., and M. Spriggs (eds), 1990. The Bougainville Crisis. Bathurst (NSW): Crawford House Press.

Meggitt, M.J., 1964. 'Male-Female Relationships in the Highlands of Australian New Guinea.' American Anthropologist 66: 204-224.

Mittermeier, R.A., C.G. Mittermeier, T.M. Brooks, J.D. Pilgrim, W.R Konstant, G.A.B. da Fonseca and C. Kormos, 2003. 'Wilderness and Biodiversity Conservation.' Proceedings of the National Academy of Sciences 100: 1030910313. doi.org/10.1073/pnas. 1732458100

Robinson, N.C., 1960. 'Report of Extended Patrol in the Native Mining Area of the Porgera River Western Highlands, August-October 1960.' Unpublished manuscript.

Shearman, P., 1995. The Environment and Social Impact of the Porgera Mine on the Strickland River System. Hobart: University of Tasmania (Honours thesis).

, 2001. 'Giving Away Another River: An Analysis of the Impacts of the Porgera Mine on the Strickland River System.' In B. Imbun and P. McGavin (eds), Mining in Papua New Guinea: Analysis and Policy Implications. Port Moresby: University of Papua New Guinea Press.

Talyaga, K., 1982. 'The Enga Yesterday and Today: A Personal Account.' In B. Carrad, D. Lea and K. Talyaga (eds), Enga: Foundations for Development. Armidale (NSW): University of New England, Department of Geography.

Vogt, C., 2012. International Assessment of Marine and Riverine Disposal of Mine Tailings. Nairobi: United Nations Environment Programme. 
Wardlow, H., 2006. Wayward Women: Sexuality and Agency in a New Guinea Society. Berkeley: University of California Press.

Weiner, J.F., 1991. The Empty Place: Poetry, Space, and Being among the Foi of Papua New Guinea. Bloomington: Indiana University Press.

Wiessner, P. and A. Tumu, 1998. Historical Vines: Enga Networks of Exchange, Ritual, and Warfare in Papua New Guinea. Washington (DC): Smithsonian Institution Press.

Winchomba, K.A., 1970. 'Porgera Patrol Report 1 of 1969/70: Western Highlands District.' Port Moresby: Territory of Papua and New Guinea, Director of Native Affairs. 
This text is taken from Island Rivers: Fresh Water and Place in Oceania, edited by John R. Wagner and Jerry K. Jacka, published 2018 by ANU Press, The Australian National University, Canberra, Australia.

doi.org/10.22459/IR.06.2018.05 